\section{Biochemical and haematological variables in vegetarians}

Relatively little is known about the long-term consequences of a vegetarian diet. Vegetarians have lower serum cholesterol concentrations than non-vegetarians ${ }^{1}$ and Seventh-Day Adventists in the United States of America appear to have a lower prevalence of ischaemic heart disease than the general population. ${ }^{2}$ On the other hand, vegetarian diets may be associated with impaired calcium absorption and with anaemia. We have recently measured various biochemical and haematological variables in two groups of vegetarians and a group of non-vegetarians.

\section{Subjects, methods, and results}

The subjects studied were (1) 56 vegetarians and 264 non-vegetarians who were volunteers in an epidemiological study which suggested a protective role of cereal fibre in diverticular disease, ${ }^{3}$ and (2) a further group of 35 vegetarians attending a vegetarian congress at Guildford in the summer of 1978. The volunteers were all aged between 30 and 69 years and the groups comprised roughly equal numbers of men and women. Fasting plasma lipid, lipoprotein, cholesterol, and glucose concentrations were measured by methods we have previously described. ${ }^{4}$ The other variables (see table) were measured in the clinical biochemistry laboratory of the Radcliffe Infirmary, Oxford. All measurements were made without knowledge of whether the samples were from vegetarians or non-vegetarians. The significance of differences between groups was assessed by means of the unpaired $t$ test.

Selected results are shown in the table. Analyses of the diet histories suggested that the difference in cholesterol concentrations might be because of a difference in saturated fat intake rather than because vegetarians had a higher intake of dietary fibre. Vegetarians with a saturated and monounsaturated fat intake of over $50 \mathrm{~g}$ daily had a mean plasma cholesterol concentration of $6.2 \mathrm{mmol} / 1(239 \mathrm{mg} / 100 \mathrm{ml})$, which is similar to that in non-vegetarians. No relationship was apparent between cholesterol and dietary fibre. The differences in blood glucose and high density lipoprotein (HDL) expressed as a percentage of total cholesterol were small but consistent and statistically significant. Despite calcium and haemoglobin concentrations being lower in vegetarians none were anaemic: the lowest calcium concentration was $2.21 \mathrm{mmol} / 1(8.8 \mathrm{mg} / 100 \mathrm{ml})$. None of the differences between groups could be explained by differences in age and sex. The 35 vegetarians in group 2 were studied in the summer, whereas the vegetarians and non-vegetarians in group 1 were studied over the course of a year. Numbers were too few to examine for seasonal variation in detail, but there were no appreciable differences between the two groups. Relevant negative results are also shown in the table. There was no difference in the results of liver function tests and other measurements usually made in a routine SMA screen and full blood count between vegetarians and non-vegetarians.

Mean $( \pm S D)$ values for various biochemical and haematological variables in vegetarians and non-vegetarians

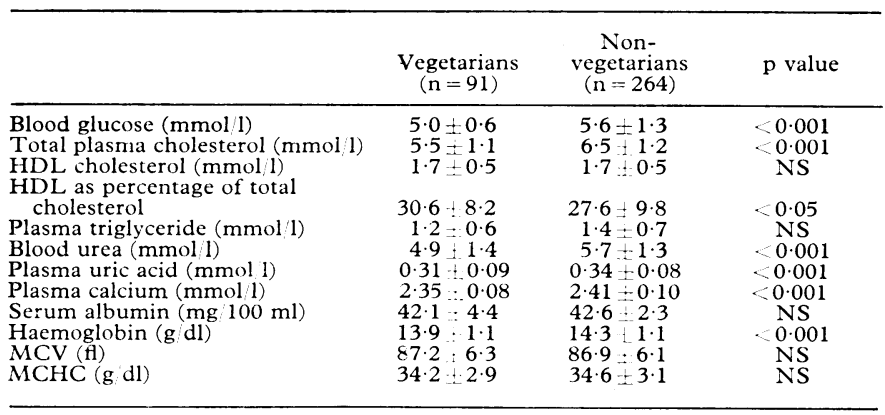

Conversion: SI to traditional unit

Blood glucose: $1 \mathrm{mmol} 1$ = $18 \mathrm{mg} 100 \mathrm{ml}$

Plasma cholesterol: $1 \mathrm{mmol} 1=38.6 \mathrm{mg} / 100 \mathrm{ml}$

Plasma triglyceride: $1 \mathrm{mmol} 1=88.5 \mathrm{mg} 100 \mathrm{ml}$

Blood urea: $1 \mathrm{mmol} / 1 \approx 6.0 \mathrm{mg} / 100 \mathrm{ml}$

Plasma uric acid: $1 \mathrm{mmol} 1 \approx 16 \cdot 8 \mathrm{mg} 100 \mathrm{ml}$

Plasma calcium: $1 \mathrm{mmol} 1 \approx 4.0 \mathrm{mg}$
Mean cell vol $(\mathrm{MCV}): 1 \mathrm{fl}=1 \mathrm{~km}^{3}$

\section{Comment}

The vegetarians studied were all members of the Vegetarian Society of the United Kingdom and consequently not necessarily representative of all vegetarians. The data are nevertheless of interest, and some of the differences may explain at least in part the low prevalence of ischaemic heart disease in the largely vegetarian Seventh-
Day Adventists. ${ }^{2}$ The data confirm the need for a long-term prospective study of vegetarians, whose indicators of carbohydrate and lipid metabolism (including the ratio of HDL to total cholesterol ${ }^{5}$ ) seem to be more favourable to health than those of non-vegetarians.

We thank the members of the Vegetarian Society of the United Kingdom and the non-vegetarians for their help, and also Dr R Wilkinson of the Department of Clinical Biochemistry, Radcliffe Infirmary.

${ }^{1}$ Sacks FM, Castelli WP, Donner A, Kass E. Plasma lipids and lipoproteins in vegetarians and controls. $N$ Engl f Med 1975;292:1148-51.

2 Phillips RL, Lemon FR, Lawrence-Beeson W, Kuzma JW. Coronary heart disease mortality among seventh-day adventists with differing dietary habits: a preliminary report. Am $\mathcal{F}$ Clin Nutr 1978;31, suppl: 5191-8.

${ }^{3}$ Gear J, Ware A, Fursdon P, et al. Symptomless diverticular disease and intake of dietary fibre. Lancet 1979;i:511-3.

- Simpson RW, Mann JI, Eaton J, Moore RA, Carter R, Hockaday TDR. Improved glucose control in maturity-onset diabetes treated with highcarbohydrate-modified fat diet. Br Med F 1979;i:1753-6.

5 Kannel WB, Castelli WP. Is the serum cholesterol an anachronism? Lancet 1979 ;ii:950-1.

(Accepted 4 March 1980)

Department of Social and Community Medicine and Diabetes

Research Laboratory, University of Oxford, Oxford.

J S GEAR, DPHIL, FCPSA, Nuffield dominion fellow

J I MANN, DM, PHD, university lecturer

M THOROGOOD, BSC, research associate

R CARTER, MIST, medical laboratory scientific officer

R JELFS, MIST, medical laboratory scientific officer

\section{Interaction between carbamazepine and warfarin}

Several anticonvulsants increase the rate of metabolism of warfarin and reduce its hypoprothrombinaemic effect. This is due to induction of hepatic microsomal enzymes. ${ }^{12}$ Carbamazepine induces microsomal enzymes in man and shortens the plasma half life of warfarin, lowers serum warfarin concentrations, and reduces the hypoprothrombinaemic effect under controlled conditions. ${ }^{3}$ We know of no reports of this interaction occurring during the routine management of patients on anticoagulants. We describe a patient on warfarin in whom discontinuing carbamazepine resulted in a potentially dangerous increase in prothrombin time.

\section{Case report}

A 56-year-old man had been taking warfarin since he had an aortic valve prosthesis inserted five years before. He had been taking carbamazepine $300-600 \mathrm{mg}$ daily for 15 months for trigeminal neuralgia and his prothrombin

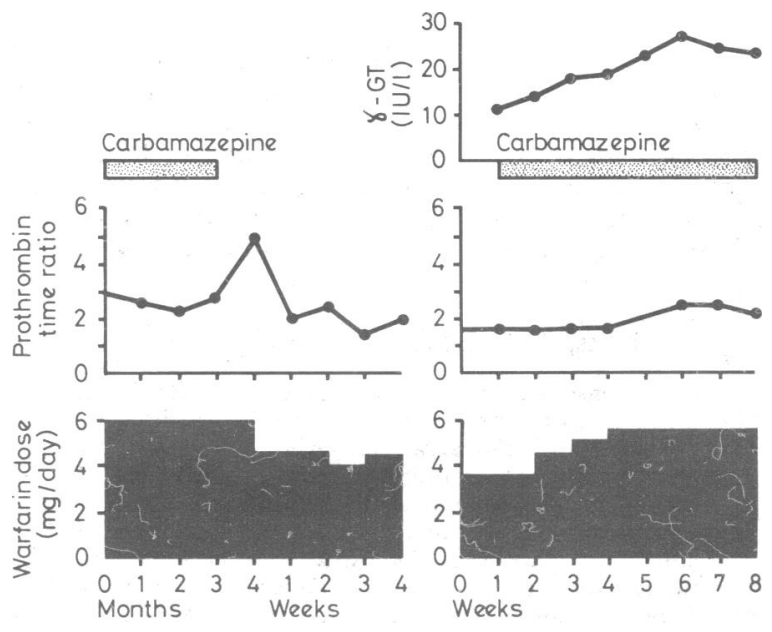

Effect of carbamazepine on warfarin dose and $\gamma$-glutamyl transferase. 
time had been stable in the therapeutic range (two to three times control) taking $6 \mathrm{mg}$ warfarin daily. He discontinued his carbamazepine, and when seen four weeks later his prothrombin time was five times control. He subsequently required $4 \mathrm{mg}$ warfarin daily to maintain his prothrombin time at two to three times control. Some months later he started taking carbamazepine $300 \mathrm{mg}$ daily again. The prothrombin time was measured weekly and his warfarin dose adjusted as necessary. His serum $\gamma$-glutamyl-transferase $(\gamma-G T)$ concentration was also measured weekly. His warfarin requirements increased from $3.5 \mathrm{mg}$ daily to $5.5 \mathrm{mg}$ daily over a period of five weeks and his serum $\gamma-\mathrm{GT}$ rose from $11 \mathrm{U} / 1$ to $27 \mathrm{U} / 1$ during the same period. The effects of carbamazepine on warfarin dose and $\gamma-\mathrm{GT}$ are shown in the figure.

\section{Comment}

Stopping carbamazepine considerably increased the effect of warfarin on the prothrombin time in this patient and restarting carbamazepine reduced the effect of warfarin, taking five weeks to reach a steady state. Hansen $e t$ al showed that giving carbamazepine to patients already taking warfarin lowered serum warfarin concentrations and warfarin half life. ${ }^{3}$ Warfarin is hydroxylated by hepatic microsomal enzymes, ${ }^{3}$ and Whitfield et al ${ }^{4}$ showed that changes in $\gamma$-GT may reflect changes in the activity of liver cell microsomal enzymes. The results in our patient suggest that this interaction may be clinically important and is probably due to increased warfarin metabolism produced by carbamazepine.

1 Remmer H. Induction of drug metabolising enzyme system in the liver. Europ f Clin Pharmacol 1972;5:116-36.

2 Latham AN, Millbank L, Richens A, Rowe DJF. Liver enzyme induction by anticonvulsant drugs, and its relationship to disturbed calcium and folic acid metabolism. F Clin Pharmacol 1973;13:337-43.

${ }^{3}$ Hansen JM, Siersbaek-Nielsen K, Skovsted L. Carbamazepine-induced acceleration of diphenylhydantoin and warfarin metabolism in man. Clin Pharmacol Ther 1971;12:539-43.

4 Whitfield JB, Moss DW, Neale G, Orme M, Breckenridge A. Changes in plasma $\gamma$-glutamyl transpeptidase activity associated with alterations in drug metabolism in man. $B r$ Med $71973 ; \mathrm{i}: 316-8$.

\section{(Accepted 26 February 1980)}

Regional Blood Transfusion Centre, Birmingham

J R Y ROSS, MRCP, senior registrar

West Midlands Adverse Drug Reaction Group, Queen Elizabeth Hospital, Birmingham B15 2TH

LINDA BEELEY, MA, MRCP, consultant clinical pharmacologist

\section{Comparison of serum 25-OH vitamin $D$ concentrations in rheumatoid arthritis and osteoarthrosis}

While occasionally there may be radiological evidence of osteomalacia in rheumatoid arthritis ${ }^{1}$ and histological osteomalacia may be found in some patients with rheumatoid arthritis and bone pain, ${ }^{2}$ the exact state of vitamin $\mathrm{D}$ metabolism in this disease remains uncertain. In a recent series of 23 patients with rheumatoid arthritis there was no biochemical evidence of osteomalacia and serum 25-hydroxy vitamin D (25-OHD) concentrations were within the normal range. ${ }^{3}$ Since serum 25-OHD concentrations can be affected by medication and lack of sunlight exposure owing to immobility, we have compared the concentrations in 30 patients with rheumatoid arthritis and 30 patients with osteoarthrosis, all sufficiently severe to be admitted to hospital, to show any alterations caused by rheumatoid arthritis.

\section{Patients, methods, and results}

We studied 60 consecutive patients admitted to the Royal Bath Hospital, Harrogate: 30 had classical or definite rheumatoid arthritis (ARA criteria) and 30 had osteoarthrosis (moderate or severe osteoarthrotic changes on $x$-ray examination, normal erythrocyte sedimentation rate (ESR), and negative serology for rheumatoid factor). Both groups were bled in the fasting state concurrently between November and December 1978 on the first day of admission to hospital. Blood was measured for full blood count, ESR, calcium, liver function tests, rheumatoid factor, and plasma 25-OHD A dietary survey was made and exposure to sunlight quantified by a questionnaire and simple scoring system. ${ }^{5}$ Patients in the two groups were well
Comparisons in patients with osteoarthrosis and patients with rheumatoid arthritis (means $\pm S D$ )

\begin{tabular}{|c|c|c|c|}
\hline & & $\begin{array}{l}\text { Osteoarthrosis } \\
(\mathrm{n}=30)\end{array}$ & $\begin{array}{l}\text { Rheumatoid } \\
\text { arthritis } \\
(\mathrm{n}=30)\end{array}$ \\
\hline 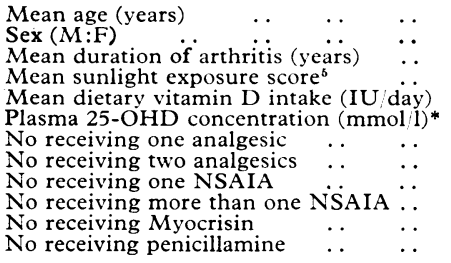 & $\begin{array}{l}\cdots \\
\cdots \\
\cdots \\
\cdots \\
\cdots \\
\cdots \\
\cdots \\
\cdots\end{array}$ & $\begin{array}{l}63 \cdot 3 \div 15 \cdot 0 \\
8: 22 \\
12 \cdot 7 \pm 8 \cdot 9 \\
25 \cdot 1=10 \cdot 5 \\
240 \div 185 \\
40 \cdot 13 \pm 43 \cdot 27 \\
14 \\
4 \\
17 \\
3 \\
=\end{array}$ & $\begin{array}{l}60 \cdot 8+9 \cdot 5 \\
10: 20 \\
13 \cdot 7 \pm 9 \cdot 8 \\
23 \cdot 2 \div 11 \cdot 4 \\
234=154 \\
59 \cdot 33=51 \cdot 58 \\
18 \\
\frac{19}{19} \\
7 \\
10 \\
2\end{array}$ \\
\hline
\end{tabular}

*Normal range $12.5 \mathrm{mmol} 1-181.25 \mathrm{mmol} / 1$

Conversion: SI to traditional units-Plasma 25-OHD: $1 \mathrm{mmol} 1 \approx 0.4 \mathrm{mg} / \mathrm{ml}$.

matched for age, sex, duration of arthritis, exposure to sunlight, and dietary vitamin $\mathrm{D}$ intake (table). Details of drug treatment, including non-steroidal anti-inflammatory agents (NSAIA), for both groups are also shown in the table.

The difference between the mean plasma 25-OHD concentration in rheumatoid arthritis $(59.33 \mathrm{mmol} / 1(23.73 \mathrm{mg} / \mathrm{ml}))$ and in osteoarthrosis $(40.13 \mathrm{mmol} / 1(16.05 \mathrm{mg} / \mathrm{ml}))$ was not significant. A reduction in $25-\mathrm{OHD}$ concentrations was seen with age in both groups. There was no significant difference between the groups in any biochemical value measured, though the alkaline phosphatase was slightly higher in the rheumatoid group (11.87 units against 9.15 units) - a difference probably attributable to the activity of the rheumatoid disease. No significant correlations were seen between 25-OHD concentration and duration of arthritis or articular index in the rheumatoid group, though there was a trend to an inverse correlation in this group between 25-OHD and ESR $(0.1>p>0.05)$. Analysis of questionnaires showed that sunlight exposure was more important than dietary vitamin $\mathrm{D}$ in determining $25-\mathrm{OHD}$ state in both groups.

\section{Comment}

Since the 25-OHD concentrations were measured in winter before the patients had been exposed to a hospital diet or fluorescent light their plasma $25-\mathrm{OHD}$ was probably at its lowest annual value and osteomalacia at its most obvious. The two groups were well matched for all factors that might have altered vitamin D metabolism, apart from the type of arthritis. Nevertheless, there was no significant difference in their 25-OHD concentrations and the mean value in the rheumatoid arthritis patients was similar to that recently reported $(68.7 \mathrm{mmol} / \mathrm{l})$ by Kennedy et al. ${ }^{3}$

We have found no evidence of biochemical osteomalacia in rheumatoid disease, and although osteomalacia may occasionally occur it probably does so coincidentally. 25-OHD concentrations fell with age in both groups, as they would in a normal population. The possible association between 25-OHD and ESR in rheumatoid disease deserves further study, though we have found no evidence that systemic $25-\mathrm{OHD}$ concentrations relate to the degree of juxtaarticular osteopenia that differentiates rheumatoid arthritis from osteoarthrosis.

We acknowledge the financial support of Roche Products Limited, and thank Mrs D K Smith for secretarial help.

${ }^{1}$ Maddison PJ, Bacon PA. Vitamin D deficiency, spontaneous fractures, and osteopenia in rheumatoid arthritis. $\mathrm{Br}$ Med $\mathcal{f} 1974$;iv:433-5.

${ }^{2}$ Bird HA. Bone biopsy in the investigation of bone pain and fractures. Rheumatol Rehabil 1979;18:38-42.

${ }^{3}$ Kennedy AC, Allam BF, Rooney PJ, et al. Hypercalcaemia in rheumatoid arthritis; investigation of its causes and implications. Ann Rheum Dis $1979 ; 38: 401-12$

4 Morris JF, Peacock M. Assay of plasma 25-hydroxy vitamin D. Clin Chim Acta $1976 ; 72: 383-91$

${ }^{5}$ Hodkinson HM, Round P, Stanton BR, Morgan C. Sunlight, vitamin D, and osteomalacia in the elderly. Lancet 1973;ii:910-2.

(Accepted 4 March 1980)

University of Leeds Rheumatism Research and Mineral Metabolism

Units, School of Medicine, Leeds LS2 9PJ

H A BIRD, MB, MRCP, lecturer in rheumatology

$M$ PEACOCK, MB, FRCP, senior lecturer and consultant physician

J H STORER, BSC, PHD, research officer

$\mathrm{V}$ WRIGHT, MD, FRCP, professor of rheumatology 